Bernadette Huyer-May

\title{
Do relationship transitions affect body weight? Evidence from German longitudinal data
}

\section{Beeinflussen Übergänge in der Partnerschaft das Körpergewicht? Ergebnisse einer deutschen Panelstudie}

\begin{abstract}
:
Despite a considerable amount of empirical studies it is still unclear if changes in union status affect body weight. Using data from the first seven waves of the German Panel Analysis of Intimate Relationships and Family Dynamics (pairfam) project, the current study aims to discover if changes in relationship status lead to changes in body weight considering multiple union transitions with fixed-effects panel regression estimations. Results show that women lose weight within the first year of a relationship, and then gain weight after entering into a non-married cohabiting relationship. Men tend to gain weight from the beginning of the partnership. The results clearly show that the transition from non-married cohabitation to marriage has no significant effect on body weight.
\end{abstract}

Key words: union transitions; body weight; marriage market hypothesis; Germany; pairfam

\section{Zusammenfassung:}

Trotz zahlreicher Studien gibt es derzeit immer noch keine gesicherten Erkenntnisse darüber, inwieweit partnerschaftliche Veränderungen Einfluss auf das Körpergewicht haben. Basierend auf den Daten der ersten sieben Wellen des deutschen Panels Analysis of Intimate Relationships and Family Dynamics (pairfam) hat diese Studie das Ziel herauszufinden, ob Veränderungen des Beziehungsstatus zu einer Veränderung des Körpergewichts führen. Dabei werden verschiedene partnerschaftliche Übergänge mit Fixed-Effect Panel Regressionen betrachtet. Die Ergebnisse zeigen, dass Frauen in dem ersten Jahr ihrer Beziehung Gewicht verlieren, dann aber an Gewicht zunehmen, wenn sie mit ihrem Partner zusammen ziehen. Männer hingegen tendieren von Beginn an ihrer Beziehung zu einer Gewichtszunahme. Die Ergebnisse zeigen deutlich, dass der Übergang von einer nicht-ehelichen Lebensgemeinschaft zur Ehe keinen Effekt auf das Körpergewicht hat.

Schlagwörter: partnerschaftliche Übergänge; Körpergewicht; Paneldaten; pairfam; Deutschland

\section{Introduction}

Obesity is a major public health issue in most Western societies, with a rapidly increasing prevalence among both men and women (Berghöfer et al. 2008; Cole et al. 2000; Ogden 
et al. 2006). Germany ranks high on the list of nations with an elevated prevalence of overweight and obesity citizens. According to the German Health Interview and Examination Survey for Adults, $67.1 \%$ of men and $53.0 \%$ of women are overweight (Mensink et al. 2013). Being overweight or obese not only increases a person's chance of health problems such as type two diabetes, cardiovascular disease, and some cancers (see for example Kopelman 2000), but obese individuals often experience multiple forms of discrimination (Carr/Friedman 2005; Puhl/Brownell 2001) as well as a lack of psychological well-being (Wadsworth/Pendergast 2014). Experts agree that weight changes - both losses and gains - carry an increased mortality risk (Mikkelsen et al. 1999), whereas a stable body weight is ideal for general good health (Umberson/Liu/Powers 2009). A better understanding of which factors determine changes in adult body weight is therefore crucial.

A growing body of literature indicates that transitions into and out of marriage may be related to changes in body weight (see Dinour et al. 2012 for an overview). Although there is a broad consensus that marital status is positively linked with health outcomes and mortality (see for example Wilson/Oswald 2005), the positive protection effect does not hold with regard to body weight (Umberson et al. 2009). However, these results are inconsistent and mostly limited to the United States, whereas research in Europe has addressed this topic only rarely thus far. Most studies suggest that the entry into marriage may be associated with weight gain (Averett/Sikora/Argys 2008; Harris/Lee/DeLeone 2010; Rauschenbach/Sobal/Frongillo 1995; Sobal/Rauschenbach/Frongillo 2003; The/GordonLarsen 2009), whereas exit from a marriage may contribute to weight loss (Eng et al. 2005; Lee et al. 2005). However, newer studies (Teachman 2016; Umberson et al. 2009) cast doubt as to if the transition into marriage in fact has an impact on body weight at all. Umberson et al. (2009) and Teachman (2016) conclude that the only transition which affects body weight is the transition out of marriage, while effects of transitions into marriage "are conditioned on a latent trajectory of weight gain across time" (Teachman 2016: 90).

This study aims to discover if changes in relationship status lead to changes in body weight considering multiple union transitions with fixed-effects panel regression estimations. This approach complements previous research in several ways: thus far, most literature refers to North America, whereas research in Europe has addressed this topic only rarely. To my knowledge, two further studies have examined the impact of marital status on body weight in Germany based on cross-sectional data (Klein 2011; Klein/Rapp/Schneider 2013), but to date no study has addressed this topic using longitudinal data for Germany. A recently published study compared BMI values of non-married to married respondents in nine European countries (Mata/Frank/Hertwig 2015). Their results show that, on average, never married respondents had a lower BMI than do married respondents. However, their analyses are based on cross-sectional data sets which could consequently be biased due to the presence of unobserved heterogeneity, as the authors do not deal with the problem of selectivity. This is essential when analyzing the link between unit transitions and body weight changes, as one could assume that selection into marriage is affected by body weight when considering that thinner (or rather: healthier) individuals are more likely to be selected as marriage partners (see Averett et al. 2008 for similar arguments). Indeed, research shows that overweight young women have higher odds to stay unmarried in comparison to their normal weight counterparts (Carmalt et al. 2008; Frisco et al. 2012:1709; Mukhopadhyay 2008). 
By using longitudinal data from the German Panel Analysis of Intimate Relationships and Family Dynamics (pairfam), a large panel study running annually since 2008 with a random sample of 12,400 participants in adolescence, young adulthood, and middle adulthood (Brüderl et al. 2016), I address this gap in research for Germany. The pairfam data set provides detailed information about union formation and relationship development and due to the young age of the respondents there is enough variation in relationship status over time. For this reason, it is possible to examine multiple union transitions, such as both the transition into non-married cohabitation, as well as out of this state into a marriage. Most studies on this subject have focused only on the entry into marriage, whereas entry into unmarried cohabitation was paid little attention. The prevalence of non-married cohabitation has considerably increased in recent years in most Western societies (Heuveline/Timberlake 2004) as more and more couples are choosing to cohabit as either a precursor or an alternative to marriage (Wu/Hart 2002: 430). According to the pairfam Panel, $88 \%$ of respondents in western Germany and $97 \%$ of respondents in eastern Germany cohabit prior to marriage (Goldstein et al. 2010) Hence, to understand how union transitions affect changes in body weight it is important to take living arrangements before cohabiting marriage into account.

To my knowledge, this is the first study to investigate the impact of all relevant trajectories of institutionalization in partnership and examine the effects of transitions into noncohabiting relationships, non-married cohabitation, and cohabiting marriage. Every unit transition is analyzed as a singular event in separate models using fixed effects models. In this analytic strategy, different estimation samples are employed, which are closer to the causal impact due to distinct control and treatment groups. Results show that the transition from non-married cohabitation to marriage has no effect on body weight. Moreover, women appear to lose weight within the first year of dating and then gain weight after moving in together with their partner, while men tend to gain weight from the very beginning of the relationship. Considering multiple union transitions can help highlight the underlying mechanisms which cause the hypothesized association between union transitions and body weight. The most prominent explanations in this regard are the marriage market hypothesis and the social obligation hypothesis ${ }^{1}$, which I describe in the next section.

1 Two further explanations have been suggested: the marriage protective hypothesis and the crises model. The marriage protective hypothesis links marital and general health status: Married individuals have higher socioeconomic status and social support and purchase better medical health due to pooled resources and specialization by the family members (Wilson 2012). Further, individuals should lose weight after entry into marriage. However, to my knowledge, no study thus far has found such a positive relationship. Despite this, some authors indicate the possibility of adverse selection, meaning that individuals with poor health have higher incentives to marry (Averett et al. 2008). The crises model concerns primarily the negative consequences of marital dissolution on body weight based on the assumption that transition out of marriage is associated with stress resulting in short-lived weight loss. 


\section{Background}

\subsection{Mechanisms}

Why should changes in relationship status affect body weight? One explanation which is often quoted is the marriage market hypothesis, based on the assumption that non-married individuals attempt to minimize weight gain in order to be more attractive to potential partners, as body weight is closely associated with physical attractiveness, good health, and reproductive potential. As a result of having "exited" the marriage market, married individuals are no longer as concerned about their body weight and, therefore, allow their weight to rise (Averett et al. 2008; Klein 2011; Rapp/Schneider 2013). Considering the increasing prevalence of cohabitating couples, the question arises as to whether a perceived exit from the marriage market begins with marriage, or rather with moving in together with a partner in a cohabiting, marriage-like relationship. Although cohabitation has become a common living arrangement, it is not equivalent to marriage in several aspects. The most obvious difference relates to the formal license: because of the lack of a recognized legal status, dissolution of non-married cohabitation is less costly than a divorce. As a consequence, cohabitation is characterized by higher instability than are married unions, as well as a decreased willingness to invest in relationship-specific capital such as joint children (Mukhopadhyay 2008).

As cohabiting couples may differ in their levels of trust in the longevity of their relationship as well as their belief in a permanent release from the marriage market, they may - in contrast to married couples - continue to see themselves as marriage market participants and thus feel greater pressure to maintain a lower weight (Averett et al. 2008; Klein/ Rapp/Schneider 2013; Rapp/Schneider 2013). Therefore, body weight should rise with an increase in relationship stability.

Thus far, several longitudinal studies have assessed the association of transitions into non-married and married cohabitation, respectively, with body weight (Dinour et al. 2012), but results are mixed. ${ }^{2}$ Using data from the National Longitudinal Study of Adolescent Health (Add Health), Harris et al. (2010) considered correlations between early marriage, cohabitation, and health for African Americans and Caucasians during the transition to adulthood in the United States. According to their results, a transition into marriage is associated with an increase in BMI across ethnicities. In contrast, they did not find a relationship between the transition into cohabitation and increased BMI. Similar results were found by Shafer (2010) using panel data from the 1979 National Longitudinal Study of Youth (USA). For women, she found no association between cohabitation and an increase in BMI, but for men cohabitation is positively associated with an increase in BMI, albeit smaller than the increase associated with marriage (Shafer 2010: 1177). She also found an association between marriage and body weight gain. However, while using the same panel data from the National Longitudinal Study of Youth (1979) Averett et al. (2008) observed a significant impact of cohabitation and marriage on BMI for both men and women. According to their results, the impact of cohabitation was smaller than that of

2 Here, I review only studies based on longitudinal data which take cohabiting living arrangements into account. 
marriage, their results lining up with the marriage market hypothesis as well as the assumption that cohabitation is not perceived to be as stable a partnership as is formal marriage (Averett et al. 2008: 15). In addition, they found that women who had ever been married were thinner than their never-married counterparts. They argued that "this supports the argument that thinness (attractiveness) among women is valued in the marriage market" (Averett et al. 2008: 14). Teachman (2016) also used data from the NLSY79 to examine the link between the transition into cohabitation and marriage and body weight. According to the latent growth curve model suggested in order to examine the joint effect of marital status and marital transition on body weight, he concluded that the only transition which affects body weight is the transition out of marriage, while effects of transitions into cohabitation and marriage are conditioned on a general tendency to gain weight with increasing age (Teachman 2016: 90). However, his results also showed that both cohabiting and married respondents tended to weigh more when compared to their single counterparts. He concluded that "marital status is more important for determining differences in body weight than transitions in marital status" (Teachman 2016: 91). However, one might assume that body weight is more affected by changes in relationship status due to the important changes in one's social environment from a theoretical perspective. A similar argument can be found in Umberson et al. (2009). Using data from the Americans' Changing Lives (ACL) Survey, the authors found neither effects of transition into marriage nor effects of continuous marital status on body weight after controlling for sociodemographic factors. However, they did observe a significant effect of the transition out of marriage, and concluded that marital transitions are more significant than marriage status (Umberson et al. 2009: 338).

Further, it has been argued that as a consequence of the perceived lower pressure to maintain body weight, sedentary behaviors may become more prevalent with the transition to marriage. Married couples are expected to spend more of their leisure time engaged in inactive behavior as opposed to physical activity (Rapp/Schneider 2013; Schmeer 2012). Rapp and Schneider (2013) used data from the German Socio-Economic Panel (GSOEP) to show that being in a relationship as well as cohabiting or being married were all associated with reduced weekly physical activity for both men and women. Contrary to the predictions of the marriage market hypothesis, however, the effects of cohabitation and marriage on physical activity were very similar. The authors concluded that "this result may indicate that cohabiting and married individuals feel similarly secure about their release from the marriage market" (Rapp/Schneider 2013: 201). However, they did not explicitly model the impact of the transition from non-married to married cohabitation on physical activity.

The second prominent explanation linking changes in relationship status to changes in body weight is the social obligation hypothesis. According to this approach, individuals gain weight due to changed dietary habits after cohabiting with a partner and due to the fact that their partners eat at more frequent and regular intervals (Averett et al. 2008). Moreover, there is some research which shows that eating in the presence of familiar others increases one's food intake when compared to eating alone (Hetherington et al. 2006). For example, based on data from 22 recently married or cohabiting couples a Scottish study found that eating together with a romantic partner has an influence on the eating habits of both individuals. Couples reported eating more regular meals, spending more 
time at each meal, and eating larger quantities of food (Marshall/Anderson 2002: 204). Both women and men gained weight during the interview period (up to 12 months), and the authors reported no differences between recently married cohabiting couples and those that had recently entered unmarried cohabitation regarding weight gain. Thus, results indicate that changes in food habits are related to the presence of a partner in a shared household, regardless of whether the couple is married or not.

In connection with this explanation, another commonly mentioned fact is that individuals who enter cohabitation or marriage gain weight because they are more likely to quit smoking (Sobal et al. 2003) as they experience a greater regulation of health-related behavior (Umberson 1992; Umberson et al. 2009). However, results on this specific topic are inconsistent. For example, Homish and Leonard (2005) find some evidence that women who are married to smokers are more likely to resume smoking in the early years of their marriage. This influence seems to be more important than the spousal influence on their partner's smoking cessation. Duncan, Wilkerson, and England (2006) find no significant reductions in smoking after cohabitation, neither for men nor for women in the National Longitudinal Survey of Youth.

\subsection{Research question and hypothesis}

This study addresses two questions. Firstly, I analyze whether union transitions affect body weight. Newer studies cast doubt as to if there is a causal relationship between changes in relationship status and body weight (Teachman 2016; Umberson et al. 2009). To identify a possible causal effect, I estimate fixed effects panel regressions which compare the average body weight before and after a transition into a specific relationship status for each person, respectively. As Brüderl and Ludwig (2015) point out, fixed effects models allow the identification of causal effects under weaker assumptions by comparing within-person changes induced by a treatment event, as within-variation is not biased by unobserved heterogeneity due to self-selection. As already mentioned, selection into marriage is affected by body weight when considering that thinner individuals are more likely to self-select, or be selected, into marriage. The focus of this paper lies on the consequences of changes in relationship status on body weight. In other words, I do not aim to compare body weights between married and unmarried individuals, but rather to detect intra-individual changes of body weight after union transitions, for which fixed effects estimations are the best choice.

My second research question concerns the mechanisms responsible for the impact of union transitions on body weight. The question at hand is whether an individual's body weight increases due to changed health behavior or dietary habits after entering into cohabitation with a partner, or if individuals gain weight after unit transitions due to a decreased willingness to maintain body weight. From a theoretical point of view, two transitions are relevant for investigation: the transition from dating to non-married cohabitation, and from non-married cohabitation to married cohabitation. If the social obligation hypothesis holds true, I can assume that respondents will gain weight after moving in together with their partner, whereas an entry into marriage should not affect body weight. According to the marriage market hypothesis, however, body weight should rise with an increase in relationship stability. As marriage is the most institutionalized and therefore 
considered the most stable relationship form, this hypothesis predicts that couples will gain weight after moving in together with their partner, and again after their wedding. Finding a positive relationship between the entry into marriage (from non-married cohabitation) and body weight would provide tentative evidence in favor of the marriage market hypothesis, because I can rule out that a possible positive effect is caused by changed health behavior or dietary habits as those respondents already cohabite prior to marriage. ${ }^{3,4}$ For the sake of completeness, I look first at the entry into a non-cohabiting romantic relationship, as body weight could theoretically already be affected by this first transition if e.g. individuals consequently reduce their physical activity (Rapp/Schneider 2013). ${ }^{5}$

\section{Method}

\subsection{Data}

The data used in this analysis are the first seven waves of the German Family Panel pairfam Release 7.0 (Brüderl et al. 2016), a large, nationwide, randomly sampled panel study of German-speaking persons (irrespective of their nationality) living in private households in Germany from three birth cohorts: 1991-1993, 1981-1983, and 1971-1973 (for more details, see Huinink et al., 2011). The pairfam panel is an annual computer-assisted survey which began in 2008/2009 with a sample of 12,400 participants in adolescence (15-17 years), young adulthood (25-27 years), and middle adulthood (35-37 years). With a planned duration of 14 years, pairfam covers the most important relationship and family formation stages from age 15 to 50 . Although only the first seven waves are available to date, detailed information on union formation and development have been collected making these data highly suitable for the research question at hand. Due to the young age of respondents, several changes in relationship status have been reported over the waves. As the focus is on individuals who changed relationship status, it is beneficial to have multiple union transitions when available (Kohn/Averett 2014).

3 In this paper I limit my analyses to unit formation. The association between union dissolution on BMI is well documented (Averett et al. 2008; Teachman 2016; Umberson et al. 2009). Some authors explain that weight loss among divorced individuals with the marriage market hypotheses as divorced individuals try to lower their body weight in order to increase their chances on the marriage market (Lundborg/Nystedt/Lindgren 2007).

4 Please note that respondents who did not cohabite prior to marriage are not considered in the analysis because the investigation from non-cohabiting to cohabiting marriage does not allow disentangling the marriage market hypothesis and the social obligation hypothesis. However, as cohabitation prior to marriage is widespread in Germany, this concerns only a small, selective group of respondents.

5 It should be noted that „first transition“ does not mean that the analysis is limited to the first intimate relationship of the respondents, but referring to the entry in the current relationship as the first of three potential transitions (entry into non-cohabiting relationship, entry into cohabitation, and marriage). 


\subsection{Measures}

\subsubsection{Dependent variable}

Following existing research, I use BMI as the dependent variable for each model. BMI is calculated from self-reported weight (in kilograms) divided by the square of self-reported height (in meters). ${ }^{6}$ Respondent weight was collected every two years (waves $1,3,5$, and 7), whereas information on height was collected in the first wave for the older two cohorts and again in the third wave for the youngest cohort. For later waves, I use the height information measured in the first or third wave, as available.

\subsubsection{Independent variables}

The central independent variables in the models are changes in relationship status: transition into a non-cohabiting romantic relationship, transition from non-cohabiting dating to never-married cohabitation, and transition from never-married cohabitation to married cohabitation. As information on body weight was collected every two years, I consider only transitions occurring in a 2-year period. ${ }^{7}$ Since the beginning of the panel 1,660 respondents began a new romantic relationship, most of which belonging to the youngest cohort $(n=1,282)$ and significantly less coming from the other two (middle cohort: $n=290$, oldest cohort: $n=88$ ). Further, 628 respondents moved in together with their partner without marrying (youngest cohort: $n=283$, middle cohort: $n=285$, oldest cohort: $n=60$ ), and 463 respondents married their cohabiting partner (youngest cohort: $n=7$; middle cohort: $\mathrm{n}=356$, oldest cohort $\mathrm{n}=100)^{8}$.

\subsubsection{Control variables}

Because fixed effects regressions implicitly control for all within-person constant variables such as ethnic or educational background, only time-varying control variables were included in the models. ${ }^{9}$ I use a spare model of time-varying confounders, of which I suppose a direct effect on the treatment as well on the outcome variable. Bozoyan and Wolbring (2016) have indicated that the common strategy in social science research, con-

6 As individuals tend to overestimate their height and underestimate their weight, both self-reported height and weight could be biased (Gorber et al. 2007; Ng et al. 2011).

7 I consider changes in relationship status between wave 1 and wave 3, wave 3 and wave 5, and wave 5 and wave 7. Transitions that occurred between even and odd waves, for example "single" in wave 1 , "in a relationship" in wave 2 , and "single" again in wave 3 are not included in the analyses.

8 As only 7 respondents belonging to the youngest cohort married since the start of the panel, I exclude the youngest cohort in the estimations of models 5 and 6 .

9 In the U.S., social group differences have been suggested as control variables, particularly across ethnic and social groups (Averett et al. 2008). In Germany, ethnic group differences are less well theorized, especially because this group is very heterogeneous. Hence, I assume no ethnic group differences in the German context. The same holds true for social class differences. Even though there is evidence suggesting that individuals in higher socioeconomic groups have a healthier diet and therefore a lower body weight (see for example McLaren 2007), there is no theoretical reason why unit transitions should affect individuals’ body weight differently across social groups. 
trolling for everything potentially associated with treatment and outcome, is increasingly doubted due to the fact that it might induce new biases of estimates by overcontrol (Bozoyan/Wolbring 2016: 84). Apart from respondent age, I control for labor force status and the age of the youngest child living in the household.

Age:

The most important control variable in all models is age, as most individuals tend to gain weight with advancing age. A random-effects BMI growth curve models by gender (Figure 1) shows that an increase in BMI with age is not constant across the three cohorts, with the youngest men in particular gaining weight more rapidly in comparison to the older cohorts. For this reason, I introduce age dummies into all models to model the age effect in a most flexible way.

Figure 1: BMI RE growth curve by age and gender (with age dummies)

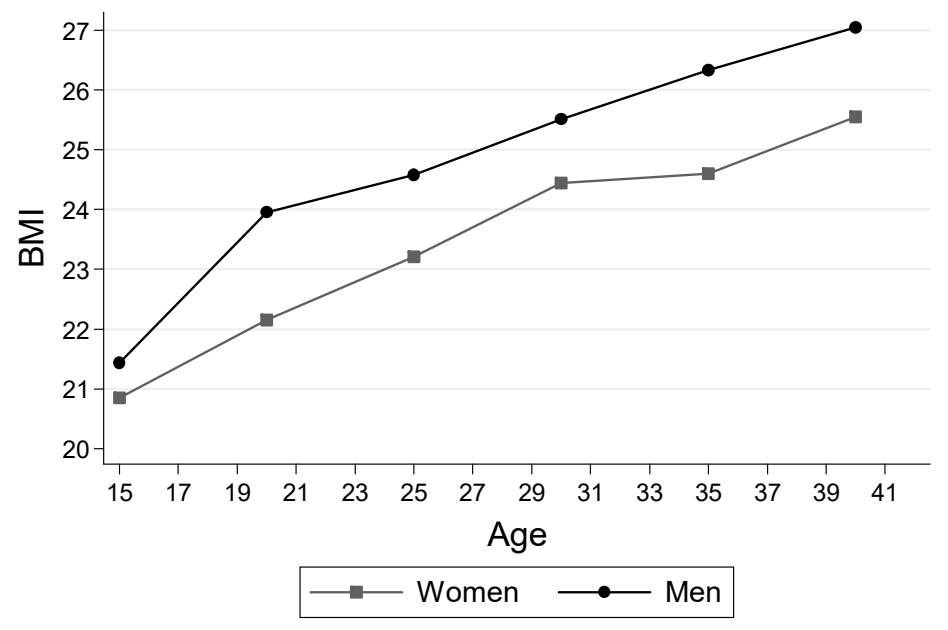

Labor force status:

Labor force status could be a potential confounder as the timing of the transition to stable employment has an important impact on marriage timing (Oppenheimer 1988) and also potentially on body weight or weight-related behavior such as time spent exercising (Nomaguchi/Bianchi 2004). I differentiate between "In education", "Currently unemployed", and "Currently employed part-time or full-time".

Age of youngest child in the household and pregnancy:

Recently published studies lend evidence to an association between the entrance into parenthood and an increase in the BMI trajectory for men as well as women (Garfield et

10 I decided to control only for labor force status and not for household income, as is typically done, because income could be a potential collider. Elwert and Winship (2014) suggest not controlling for collider variables that are e. g. caused by treatment and by outcome in order to avoid endogenous selection bias. As research on discrimination shows, wages are affected by higher BMI. On the other hand, household income is affected by relationship status as well. 
al. 2015; Umberson et al. 2011). Because marriage timing and family formation are closely linked (Perelli-Harris et al. 2012), parenthood is an important confounder when investigating the transition from non-married cohabitation to marriage. I consider the age of the youngest child using four categories: "No child in the household", "Youngest child less than one year", "Youngest child less than three years", and "Youngest child three years and older". Furthermore, I introduce a dummy variable indicating whether a female respondent is pregnant.

As there are very few changes in parenthood for male respondents and very few pregnant women who transition in a dating relationship ( $\mathrm{n}=13$ ), I decided to exclude this control variable in the case of men and exclude women who reported a pregnancy. ${ }^{11}$

\subsubsection{Intervening variables}

Previous literature has suggested three explanations as to why individuals gain weight after union transitions: a change in eating behavior (i.e. more regular meals and larger quantities of food), less exercise (Nomaguchi/Bianchi 2004; Rapp/Schneider 2013), and quitting/reducing smoking (Sobal et al. 2003; Umberson 1992). To examine these with pairfam data, I consider intervening variables after controlling for potential confounders; namely, if respondents quit smoking and if respondents exercise less than once a week. Unfortunately, eating behavior was not measured in pairfam. Should an unexplained effect of changes in relationship status be present, I would argue that this arises at least in part from changed in eating behavior due to a union transition.

\subsection{Analytic strategy}

Contrary to previous research approaches, I consider each union transition as a singular event in an attempt to approximate real conditions, as the transition from single to cohabiting or even to marriage without the intermittent step of dating do not occur under normal circumstances. I therefore employ three different estimation samples which are more conservative and closer to the causal impact due to distinct control and treatment groups. If the social obligation hypothesis holds true, I assume that respondents will gain weight after moving in together with their partner, whereas an entry into marriage should not further affect body weight of either partner. The marriage market hypothesis predicts that couples will gain weight both after moving in together and after their wedding.

The first sample was restricted to single respondents from wave 1 . The treatment group experienced the event "entry into a romantic relationship", whereas the control group remained single. ${ }^{12}$ Observations after the transition to cohabitation (in cases in which both the entry into the relationship and later the transition to cohabitation were observed) are dropped in this analysis so that only observations of single respondents and those in a non-cohabiting relationship are included. The same approach was implemented for the other samples: A second sample is restricted to include only those respondents

11 The main results remain unchanged when I include these cases in the analyses.

12 Person-years from respondents who do not experience the treatment are included as they provide the control group with more data to estimate the common age effect (Brüderl/Ludwig 2015). 
who were not cohabiting with their partner in the first wave, where the treatment group are those respondents who moved in together with their romantic partner. The control group includes those respondents who can potentially experience the treatment, i.e. either single respondents or those in an unmarried, non-cohabiting relationship. Finally, a third sample includes all unmarried respondents. Those in the control group remained unmarried across all waves, whereas those belonging to the treatment group were living in a non-married cohabiting relationship in wave 1 and got married to their cohabiting partner at some point during the first seven waves. Table 1 summarizes the analytical samples as well as the theoretical predictions derived from the marriage market hypothesis and the social obligation hypothesis. The study flow diagram in the Appendix gives an overview of omitted cases for each sample.

Table 1: $\quad$ Summary estimation samples and theoretical predictions

\begin{tabular}{lcccc}
\hline & Treatment & Control group & $\begin{array}{c}\text { Prediction marriage } \\
\text { market hypothesis }\end{array}$ & $\begin{array}{c}\text { Prediction } \\
\text { social obligation } \\
\text { hypothesis }\end{array}$ \\
\hline Sample 1 & $\begin{array}{c}\text { Transition single to dating } \\
\text { Transition dating } \\
\text { to cohabitation } \\
\text { Transition } \\
\text { Sample 2 }\end{array}$ & $\begin{array}{c}\text { Continuous single } \\
\text { Continuous w/o } \\
\text { (cohabiting) partner } \\
\text { Continuous unmarried }\end{array}$ & + & + \\
\hline
\end{tabular}

Notes: "“" indicates weight gain; “"” indicates no weight change; “-” no prediction

In all analyses, respondents with less than two valid BMI observations were excluded, along with respondents with implausible values for the dependent variable. ${ }^{13}$

As the social facilitation of eating may be stronger among men (Herman/Roth/Polivy 2003: 875), and as physical appearance has been shown to be a more important factor in female attractiveness (Averett et al. 2008), I estimate separate models for women and men. Table 2 contains mean values and standard deviations of all variables for individuals belonging to one of the three treatment groups.

13 Cases with missing data for both dependent and independent variables were excluded from the sample, resulting in $3 \%$ of all cases being lost due to missing values. Missing data for BMI (4.27 percent of all cases) may be a source of bias, as item nonresponse on sensitive questions may be selective. However, only very few respondents gave no valid answer across all waves. As one can assume that respondents would rather not state their body weight while their weight was changing, I assume that results in this study are rather conservative. 
Table 2: Mean and standard deviations (in parentheses) for individuals belonging to a treatment group

\begin{tabular}{lccc}
\hline & $\begin{array}{c}\text { Transition into } \\
\text { Dating }\end{array}$ & $\begin{array}{c}\text { Transition into } \\
\text { Cohabitation }\end{array}$ & $\begin{array}{c}\text { Transition into } \\
\text { Marriage }\end{array}$ \\
\hline BMI W1 & 21.92 & 23.09 & 24.46 \\
BMI W3 & $(3.72)$ & $(4.37)$ & $(4.54)$ \\
& 22.64 & 23.70 & 25.10 \\
BMI W5 & $(3.79)$ & $(4.55)$ & $(4.83)$ \\
& 23.16 & 24.03 & 25.55 \\
BMI W7 & $(3.79)$ & $(4.50)$ & $(4.88)$ \\
& 23.55 & 24.47 & 25.74 \\
Age & $(3.87)$ & $(4.64)$ & $(5.12)$ \\
& 21.16 & 24.98 & 30.85 \\
Labor force status: in education & $(5.87)$ & $6.71)$ & $(4.95)$ \\
Labor force status: not employed & $50.07 \%$ & $28.55 \%$ & $5.89 \%$ \\
Labor force status: employed & $6.66 \%$ & $9.01 \%$ & $12.56 \%$ \\
No children & $43.26 \%$ & $62.44 \%$ & $81.55 \%$ \\
Youngest child in the household: less than one year & $97.94 \%$ & $89.88 \%$ & $63.16 \%$ \\
Youngest child in the household: less than three years & $0.17 \%$ & $3.16 \%$ & $10.63 \%$ \\
Youngest child in the household: & $0.39 \%$ & $2.79 \%$ & $14.00 \%$ \\
3 years and older & $1.51 \%$ & $4.18 \%$ & $12.20 \%$ \\
Currently pregnant (only female respondents) & & & \\
Physically activity at least once a month & - & $1.64 \%$ & $9.48 \%$ \\
Quit smoking & $30.18 \%$ & $40.30 \%$ & $46.88 \%$ \\
Number of observations & $4.84 \%$ & $5.25 \%$ & $4.97 \%$ \\
Number of cases & 5,434 & 2,154 & 1,664 \\
Percent of all cases (starting sample) & 1,660 & 603 & 463 \\
\hline
\end{tabular}

\subsection{Results}

First, I investigate how the transition into a romantic partnership affects BMI (Table 3). Surprisingly, there is a strong gender effect: women lose weight when beginning a new relationship, whereas men appear to gain weight. In the case of women's entry into romantic relationships, a BMI decrease of $0.18 \mathrm{~kg} / \mathrm{m}^{2}$ is associated. For men, a BMI increase of $0.14 \mathrm{~kg} / \mathrm{m}^{2}$ is observed. 
Table 3: $\quad$ Fixed effects estimation results of transition to dating on BMI

\begin{tabular}{|c|c|c|c|c|}
\hline \multirow[t]{2}{*}{$\operatorname{BMI}\left(\mathrm{kg} / \mathrm{m}^{2}\right)$} & \multicolumn{2}{|c|}{ Model 1} & \multicolumn{2}{|l|}{ Model 2} \\
\hline & Men & Women & Men & Women \\
\hline Transition to dating & $\begin{array}{c}0.1429^{*} \\
(2.2256)\end{array}$ & $\begin{array}{l}-0.1761^{*} \\
(-2.3825)\end{array}$ & $\begin{array}{r}0.1348^{*} \\
(2.0992)\end{array}$ & $\begin{array}{l}-0.1790^{*} \\
(-2.4029)\end{array}$ \\
\hline $\begin{array}{l}\text { Labor force status (ref.: } \\
\text { Not employed }\end{array}$ & $\begin{array}{c}0.2345^{+} \\
(1.8204)\end{array}$ & $\begin{array}{l}0.7834^{\star *} \\
(3.2907)\end{array}$ & $\begin{array}{c}0.2260^{+} \\
(1.7504)\end{array}$ & $\begin{array}{l}0.7825^{\star *} \\
(3.2951)\end{array}$ \\
\hline Employed & $\begin{array}{l}0.2087^{* *} \\
(2.6610)\end{array}$ & $\begin{array}{r}0.0602 \\
(0.7624)\end{array}$ & $\begin{array}{r}0.2020^{*} \\
(2.5767)\end{array}$ & $\begin{array}{r}0.0593 \\
(0.7540)\end{array}$ \\
\hline Age dummies & included & included & included & included \\
\hline \multicolumn{5}{|c|}{$\begin{array}{l}\text { Youngest child in the household } \\
\text { (ref.: no child) }\end{array}$} \\
\hline Less than one year & & $\begin{array}{r}0.7801 \\
(0.9496)\end{array}$ & & $\begin{array}{r}0.7456 \\
(0.9014)\end{array}$ \\
\hline Less than three years & & $\begin{array}{r}0.3774 \\
(0.8934)\end{array}$ & & $\begin{array}{r}0.3614 \\
(0.8533)\end{array}$ \\
\hline Three years and older & & $\begin{array}{r}0.3239 \\
(1.1014)\end{array}$ & & $\begin{array}{r}0.3234 \\
(1.1037)\end{array}$ \\
\hline Quit smoking & & & $\begin{array}{r}0.2381 \\
(1.3663)\end{array}$ & $\begin{array}{r}0.1162 \\
(0.4830)\end{array}$ \\
\hline Reduced activity level & & & $\begin{array}{r}0.1164 \\
(1.4730)\end{array}$ & $\begin{array}{r}0.0504 \\
(0.5697) \\
\end{array}$ \\
\hline Observations & 5,868 & 4,242 & 5,868 & 4,242 \\
\hline Number of persons & 1,834 & 1,350 & 1,834 & 1,350 \\
\hline Number of transitions & 858 & 802 & 858 & 802 \\
\hline$R^{2}$ & 0.2383 & 0.1488 & 0.2392 & 0.1490 \\
\hline
\end{tabular}

$t$ statistics in parentheses

$+p<0.10,{ }^{*} p<0.05,{ }^{* *} p<0.01,{ }^{* * *} p<0.001$; panel robust standard errors are used.

To my knowledge, this result has not yet been reported, mainly as previous literature focused on marital transitions and did not consider the beginning of a non-cohabiting romantic relationship and its possible link to body weight changes. Yet the question arises as to how this result fits with the theoretical expectations described above. The social obligation hypothesis is related to dietary changes which occur due to the presence of a partner in a shared household. Although there is a clear suggestion of the result after moving in together with a partner, there is no specific prediction about the effect of an entry into a romantic relationship on body weight changes. ${ }^{14}$ The marriage market hypothesis, in contrast, suggests that body weight should rise with an increase in relationship stability. Hence, the positive association observed among men is in line with the marriage market hypothesis. What is less clear is the explanation for the negative effect observed among

14 However, one could assume that dietary habits might change from the beginning of a romantic relationship, as new couples spend increasingly more time together at common meals e. g. visiting restaurants or cooking together. 
women. Figures 2 and 3 show the impact of relationship duration on body weight changes for both men and women. ${ }^{15}$

Figures 2 and 3: $\quad$ Relationship duration and change in BMI for men and women $(90 \% \mathrm{CI})$
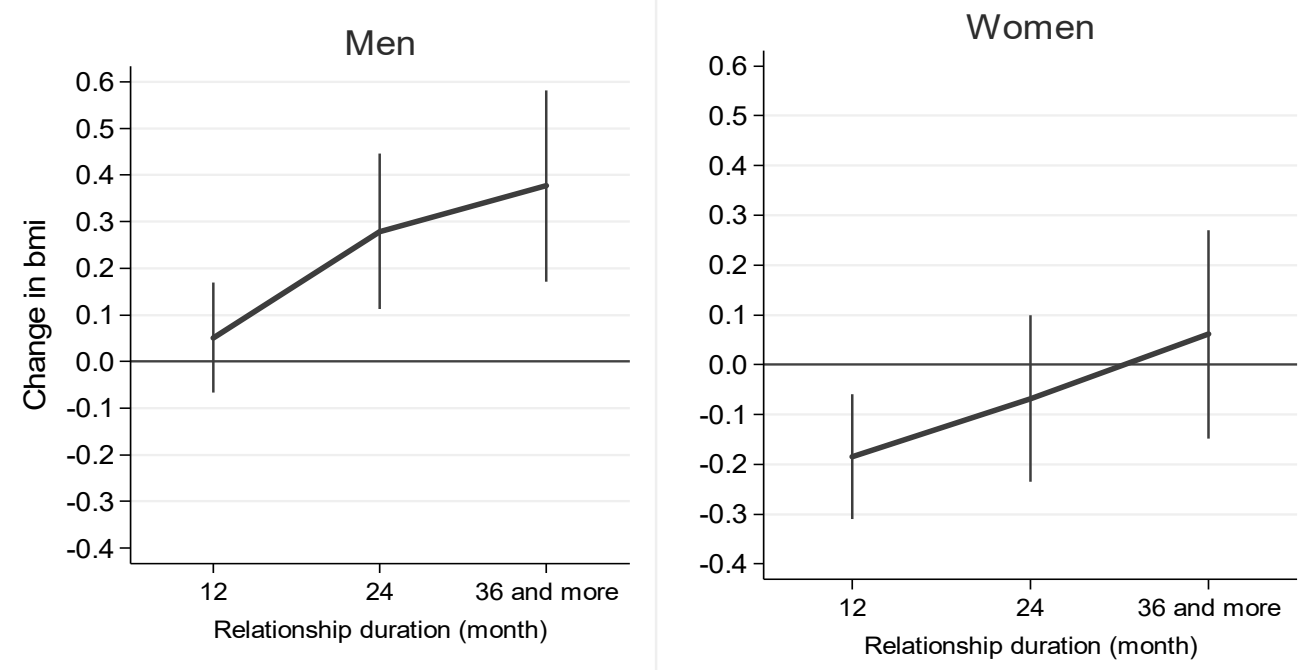

Weight loss among women occurred in the first year after entering into a relationship. Based on the assumption that women perceive their current figures to be heavier than what they believe men's preferences to be (Fallon/Rozin 1985: 104), it can be assumed that women attempt to lose body weight in order to become more attractive for their new romantic partners. ${ }^{16}$ Unlike the women in the sample, men's BMI values remained unchanged during the first year and only than begun to increase.

In addition, as can be seen from Table 3, results show that changes in labor force status affect both men's and women's body weight in different ways: after becoming employed, men's BMI increases, whereas women's body weight increased when their labor force status changed to "Not employed". However, an interpretation of control as well as intervening variables must be carefully considered, in view of the restrictive estimation samples. Moreover, it should be noted, that the category "Not employed" includes re-

15 Figures 2 and 3 show the impact of relationship duration on BMI changes for men and women. The coefficients are based on the same model and the same sample selection as Model 1. Instead of transition into relationship status, I employ relationship duration measured in form of four categories spanning 12-month-intervals. I included each category as a binary variable to allow for maximum flexibility in the model. The figures were generated using the coefplot command in STATA $(90 \%$ confidence interval).

16 An alternative explanation could be related to biological factors, as the process of falling in love is connected to hormonal changes which can result, among other things, in a reduction of appetite (Tarlaci 2012: 745). There are some indications that suggest gender differences in love (De Boer/ Van Buel/Ter Horst 2012), and it is reasonable to assume that women might be more affected. 
spondents who are currently employed as well homemakers. ${ }^{17}$ When adjusting for weekly physical activity and smoking behavior, the effect of a transition into a romantic relationship on body weight among men becomes somewhat smaller, whereas the effect among women slightly increased. This could suggest that weight changes occur due to changed dietary habits.

Next, I consider how respondent body weight changed after the transition to cohabitation. Table 4 shows that both men and women gain weight after entry into non-married cohabitation. The average BMI gain for men was $0.26 \mathrm{~kg} / \mathrm{m}^{2}$, for women $0.29 \mathrm{~kg} / \mathrm{m}^{2}$ after establishing a joint household.

As with the previous results, weight gain does not appear to be due to less exercise or a cease in smoking behavior, but probably rather to a change in eating habits as results change very little when considering both intervening variables.

Table 4: Fixed effects estimation results of transition to unmarried cohabitation on BMI

\begin{tabular}{|c|c|c|c|c|}
\hline \multirow[t]{2}{*}{ BMI $\left(\mathrm{kg} / \mathrm{m}^{2}\right)$} & \multicolumn{2}{|c|}{ Model 3} & \multicolumn{2}{|c|}{ Model 4} \\
\hline & Men & Women & Men & Women \\
\hline Transition to cohabitation & $\begin{array}{l}0.2634^{*} \\
(2.0547)\end{array}$ & $\begin{array}{l}0.2998^{*} \\
(2.5145)\end{array}$ & $\begin{array}{l}0.2566^{*} \\
(2.0110)\end{array}$ & $\begin{array}{l}0.3012^{*} \\
(2.5318)\end{array}$ \\
\hline \multicolumn{5}{|c|}{ Labor force status (ref.: in education) } \\
\hline Not employed & $\begin{array}{l}0.2111^{+} \\
(1.8509)\end{array}$ & $\begin{array}{l}0.6681^{\star * \star} \\
(3.5407)\end{array}$ & $\begin{array}{l}0.2063^{+} \\
(1.8071)\end{array}$ & $\begin{array}{l}0.6677^{* * *} \\
(3.5391)\end{array}$ \\
\hline Employed & $\begin{array}{l}0.1416^{+} \\
(1.9274)\end{array}$ & $\begin{array}{l}0.0392 \\
(0.5611)\end{array}$ & $\begin{array}{l}0.1359^{+} \\
(1.8500)\end{array}$ & $\begin{array}{l}0.0361 \\
(0.5182)\end{array}$ \\
\hline Age dummies & included & included & included & included \\
\hline \multicolumn{5}{|c|}{$\begin{array}{l}\text { Youngest child in the household } \\
\text { (ref.: no child) }\end{array}$} \\
\hline Less than one year & $\begin{array}{l}0.3431 \\
(0.9012)\end{array}$ & $\begin{array}{l}1.3135^{\star *} \\
(3.1714)\end{array}$ & $\begin{array}{l}0.3052 \\
(0.7975)\end{array}$ & $\begin{array}{l}1.2808^{* *} \\
(3.0793)\end{array}$ \\
\hline Less than three years & $\begin{array}{l}-0.1524 \\
(-0.6872)\end{array}$ & $\begin{array}{l}0.2976 \\
(1.0924)\end{array}$ & $\begin{array}{l}-0.1689 \\
(-0.7549)\end{array}$ & $\begin{array}{l}0.2771 \\
(1.0203)\end{array}$ \\
\hline Three years and older & $\begin{array}{l}-0.0324 \\
(-0.0850)\end{array}$ & $\begin{array}{l}0.5129^{*} \\
(2.3757)\end{array}$ & $\begin{array}{l}-0.0341 \\
(-0.0902)\end{array}$ & $\begin{array}{l}0.5064^{*} \\
(2.3567)\end{array}$ \\
\hline Currently pregnant & & $\begin{array}{l}1.9552^{* * *} \\
(4.3338)\end{array}$ & & $\begin{array}{l}1.9040^{* * *} \\
(4.2695)\end{array}$ \\
\hline Quit smoking & & & $\begin{array}{l}0.1225 \\
(0.8128)\end{array}$ & $\begin{array}{l}0.2416 \\
(1.2139)\end{array}$ \\
\hline Reduced activity level & & & $\begin{array}{l}0.1183^{+} \\
(1.6851)\end{array}$ & $\begin{array}{l}0.0619 \\
(0.8707)\end{array}$ \\
\hline Observations & 7,353 & 5,970 & 7,353 & 5,970 \\
\hline Number of persons & 2,287 & 1,856 & 2,287 & 1,856 \\
\hline Number of transitions & 272 & 356 & 272 & 356 \\
\hline$R^{2}$ & 0.2306 & 0.1685 & 0.2313 & 0.1691 \\
\hline
\end{tabular}

$t$ statistics in parentheses

$+p<0.10, * p<0.05, * * p<0.01, * * * p<0.001$; panel robust standard errors are used

17 When a more detailed measure for labor force status was used, results changed only slightly. 
Finally, Table 5 presents the impact of the transition from unmarried cohabitation to marriage on BMI changes. Respondents who marry their cohabiting partner do not gain weight when controlling for age, labor force status, and age of the youngest child in the household. These results provide no evidence to support the marriage market hypothesis which predicts that couples will additionally gain weight after their wedding. In other words, individuals do not gain weight after marriage because they are no longer concerned about their body weight and thus allow their weight to rise.

Table 5: $\quad$ Fixed effects estimation results of transition from unmarried cohabitation to marriage on BMI

\begin{tabular}{|c|c|c|c|c|}
\hline \multirow[t]{2}{*}{ BMI $\left(\mathrm{kg} / \mathrm{m}^{2}\right)$} & \multicolumn{2}{|c|}{ Model 5} & \multicolumn{2}{|c|}{ Model 6} \\
\hline & Men & Women & Men & Women \\
\hline Transition to marriage & $\begin{array}{l}0.0660 \\
(0.5738)\end{array}$ & $\begin{array}{l}-0.0570 \\
(-0.3767)\end{array}$ & $\begin{array}{l}0.0715 \\
(0.6231)\end{array}$ & $\begin{array}{l}-0.0435 \\
(-0.2884)\end{array}$ \\
\hline \multicolumn{5}{|c|}{ Labor force status (ref.: in education) } \\
\hline Not employed & $\begin{array}{l}-0.1874 \\
(-1.0477)\end{array}$ & $\begin{array}{l}0.0707 \\
(0.3574)\end{array}$ & $\begin{array}{l}-0.1956 \\
(-1.0980)\end{array}$ & $\begin{array}{l}0.0623 \\
(0.3131)\end{array}$ \\
\hline Employed & $\begin{array}{l}-0.3576^{* *} \\
(-2.9304)\end{array}$ & $\begin{array}{l}-0.4210^{* *} \\
(-2.8138)\end{array}$ & $\begin{array}{l}-0.3660^{* *} \\
(-3.0222)\end{array}$ & $\begin{array}{l}-0.4299^{* *} \\
(-2.8311)\end{array}$ \\
\hline Age dummies & included & included & included & included \\
\hline \multicolumn{5}{|c|}{$\begin{array}{l}\text { Youngest child in the household } \\
\text { (ref.: no child) }\end{array}$} \\
\hline Less than one year & $\begin{array}{l}0.2186 \\
(1.3376)\end{array}$ & $\begin{array}{l}0.4051^{+} \\
(1.8403)\end{array}$ & $\begin{array}{l}0.1671 \\
(1.0149)\end{array}$ & $\begin{array}{l}0.3357 \\
(1.5177)\end{array}$ \\
\hline Less than three years & $\begin{array}{l}0.0556 \\
(0.4488)\end{array}$ & $\begin{array}{l}0.0952 \\
(0.5450)\end{array}$ & $\begin{array}{l}0.0209 \\
(0.1688)\end{array}$ & $\begin{array}{l}0.0734 \\
(0.4204)\end{array}$ \\
\hline Three years and older & $\begin{array}{l}0.0851 \\
(0.5366)\end{array}$ & $\begin{array}{l}0.2040 \\
(1.3797)\end{array}$ & $\begin{array}{l}0.0748 \\
(0.4717)\end{array}$ & $\begin{array}{l}0.2036 \\
(1.3817)\end{array}$ \\
\hline Currently pregnant & & $\begin{array}{l}2.1816^{* * *} \\
(9.7800)\end{array}$ & & $\begin{array}{l}2.1363^{\star * *} \\
(9.6723)\end{array}$ \\
\hline Quit smoking & & & $\begin{array}{l}0.2019 \\
(1.4030)\end{array}$ & $\begin{array}{l}0.3965^{*} \\
(2.0568)\end{array}$ \\
\hline Reduced activity level & & & $\begin{array}{l}0.2724^{\star *} \\
(3.2611)\end{array}$ & $\begin{array}{l}0.0851 \\
(0.9854)\end{array}$ \\
\hline Observations & 3949 & 3250 & 3949 & 3250 \\
\hline Number of persons & 1,195 & 989 & 1,195 & 989 \\
\hline Number of transitions & 232 & 224 & 232 & 224 \\
\hline$R^{2}$ & 0.0988 & 0.1558 & 0.1034 & 0.1576 \\
\hline
\end{tabular}

$t$ statistics in parentheses

$+p<0.10, * p<0.05, * * p<0.01, * * * p<0.001$; panel robust standard errors are used

Figure 4 gives an overview of the main effects based on Model 1, Model 3, and Model 5 for men and women. 
Figure 4: Overview main effects unit transitions based on Model 1, Model 3, and Model $5(90 \% \mathrm{CI})$

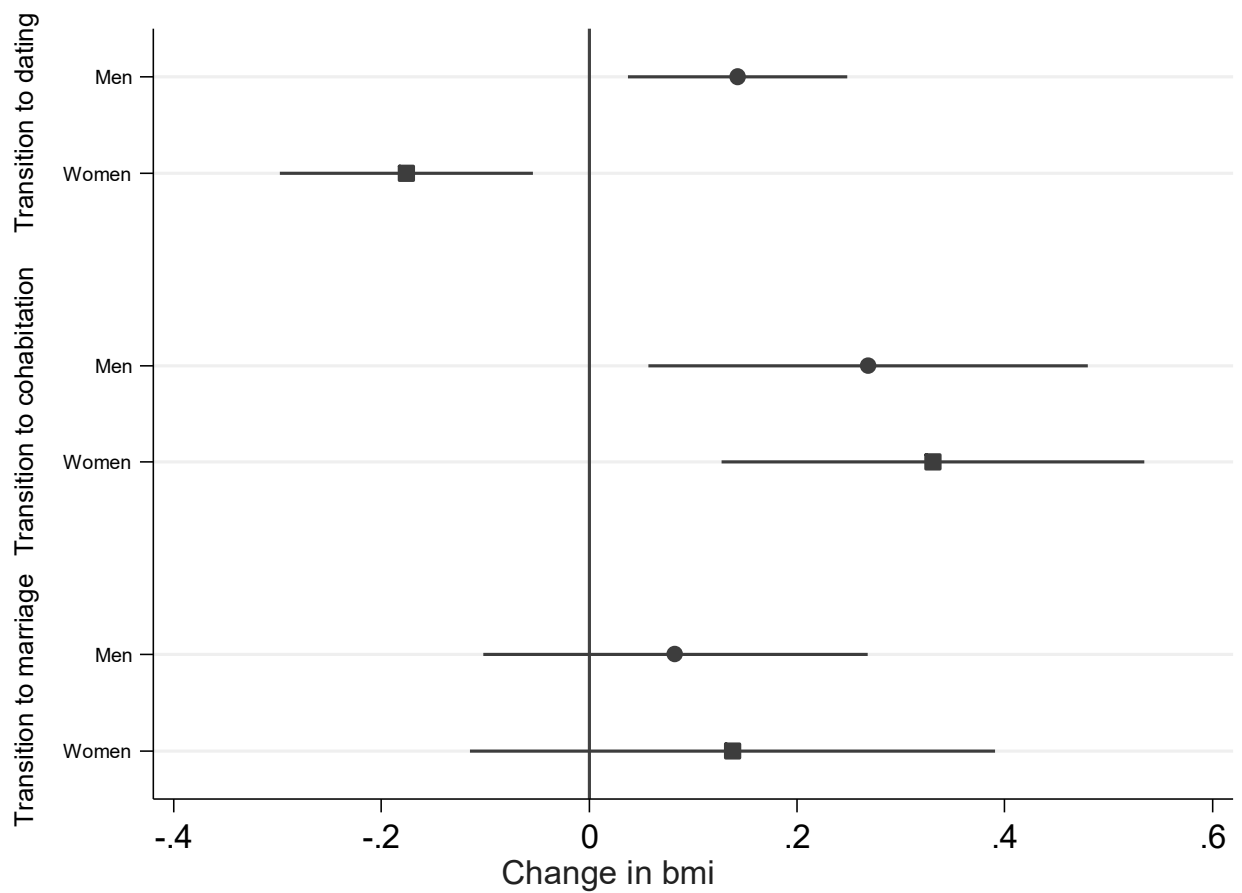

\section{Discussion}

Using German panel data, the present study examines the impact of union transitions on body weight. Drawing on seven waves of pairfam data, I employ a fixed effects approach by investigating each unit transition as a singular event with rigorous treatment and control groups. Unlike previous research, I also consider the transition into non-cohabiting, unmarried dating relationships. Results show that men already begin to exhibit an increase in body weight after starting a new non-cohabiting relationship which was then followed by a transition to cohabitation. A different picture emerges for women. Results indicate that women lose weight within the first year of a relationship and then gain weight again after a transition into cohabitation. Respondents who marry their cohabiting partner do not gain or lose weight when controlling for age, labor force status, and age of the youngest child in the household.

This study is the first to demonstrate a gender effect regarding transitioning into a new relationship status and body weight changes. However, further research is necessary to confirm these results. Interpretations of these results should proceed with caution, in particular as the effects are quite small. However, results indicate that it is important to 
differentiate between single respondents and respondents engaged in living apart together partnerships when analyzing the association between union/marital transition and body weight, as body weight seems be affected by this first transition.

The main purpose was to investigate the transition into non-married cohabitation and the subsequent transition into marriage. According to the social obligation hypothesis, individuals gain weight when they enter into a non-married cohabiting relationship, whereas the marriage market hypothesis suggests additional weight gain after the entry into a legal marriage. Results show that the transition from unmarried cohabitation to married cohabitation is not associated with weight gain, neither for men nor for women. These results provide no evidence for the marriage market hypothesis as neither women nor men experienced an increase in BMI after marrying their cohabiting partner. According to these results, the question surfaces as to whether a perceived exit from the marriage market begins with a particular event such as marriage or cohabitation, or if it is a gradual process that coincides with an increase in relationship duration. The results also suggest that body weight gain results rather from changed eating habits than reduced weekly physical activity or a reduction in or cessation of smoking behavior (both variables have only a minimal influence on changes in body weight). This somewhat surprising result might be a reflection of the relatively young age of respondents in the data and the short time period considered, as well as the restrictive estimation samples. Hence, one substantial limitation of this study is that only short-term effects of union transitions could be examined. Results do not allow for conclusions on long-term weight changes and trajectories over the life course. Based on the first seven waves, it is not possible at present to estimate the cumulative effect of unit transitions over the life course as there are very few individuals who experienced all transitions over the panel lifetime. Hence, it can not be ruled out that the positive effect on BMI for women after entry into cohabitation could be attributed to the previously observed weight loss at the beginning of the relationship.

In summary, union transitions appear to have some influence on body weight trajectories. Women lose weight within the first year of the relationship and gain weight after entering into a non-married cohabiting relationship, while men tend to gain weight from the very beginning on the partnership. Clearly, the transition from non-married cohabitation to marriage has no effect on body weight.

Further research should investigate whether these results can be reproduced using data from other countries in which unmarried cohabitation is more or less common. In addition, longitudinal studies on eating habits and physical activity could complement this research by examining the causality of the effects: is it e.g. more regular meals or a different choice of food due to a partner's preference, or rather physical activity (such as active travel) and sedentary behavior measured by accelerometers which play a role in weight loss or gain in periods of union transition. 


\section{Acknowledgement}

This paper uses data from the German Family Panel pairfam, coordinated by Josef Brüderl, Karsten Hank, Johannes Huinink, Bernhard Nauck, Franz Neyer, and Sabine Walper. pairfam is funded as long-term project by the German Research Foundation (DFG). The author thanks Claudia Schmiedeberg and Madison Garrett for helpful comments.

\section{References}

Averett, S. L., Sikora, A., \& Argys, L. M. (2008). For better or worse: Relationship status and body mass index. Economics \& Human Biology, 6, 3, pp. 330-349. doi:10.1016/j.ehb.2008.07.003.

Berghöfer, A., Pischon, T., Reinhold, T., Apovian, C. M., Sharma, A. M., \& Willich, S. N. (2008). Obesity prevalence from a European perspective: A systematic review. BMC Public Health, 8, 1, pp. 200. doi:10.1186/1471-2458-8-200.

Bozoyan, C. \& Wolbring, T. (2016). The usefulness of directed acyclic graphs: What can dags contribute to a residual approach to weight-related income discrimination? Schmollers Jahrbuch, 135, 1, pp. 83-96. doi:10.3790/schm.135.1.83.

Brüderl, J. \& Ludwig, V. (2015). Fixed-effects panel regression. In: Best, H. \& Wolf, C. (Eds.), The Sage handbook of regression analysis and causal inference. Thousand Oaks: Sage, pp. 327-357. http://www.gbv.de/dms/zbw/773340963.pdf.

Brüderl, J., Hank, K., Huinink, J. et al. (2017). The German Family Panel (pairfam). GESIS Data Archive, Cologne. ZA5678 Data file Version 8.0.0.doi: 10.4232/pairfam.5678.8.0.0.

Carmalt, J. H., Cawley, J., Joyner, K., \& Sobal, J. (2008). Body weight and matching with a physically attractive romantic partner. Journal of Marriage and Family, 70, 5, pp. 1287-1296. doi:10.1111/j.1741-3737.2008.00566.x.

Carr, D. \& Friedman, M. A. (2005). Is obesity stigmatizing? Body weight, perceived discrimination, and psychological well-being in the United States. Journal of Health and Social Behavior, 46, 3, pp. 244-259. doi:10.1177/002214650504600303.

Cole, T. J., Bellizzi, M. C., Flegal, K. M., \& Dietz, W. H. (2000). Establishing a standard definition for child overweight and obesity worldwide: International survey. BMJ, 320, 7244, pp. 1240-1243. doi:10.1136/bmj.320.7244.1240.

De Boer, A., Van Buel, E. M., \& Ter Horst, G. J. (2012). Love is more than just a kiss: A neurobiological perspective on love and affection. Neuroscience, 201, pp. 114-124. doi:10.1016/j.neuroscience.2011.11.017.

Dinour, L., Leung, M. M., Tripicchio, G., Khan, S., \& Yeh, M.-C. (2012). The association between marital transitions, body mass index, and weight: A review of the literature. Journal of Obesity, 2012, 16 pages. doi.org/10.1155/2012/294974.

Duncan, G. J., Wilkerson, B., \& England, P. (2006). Cleaning up their act: The effects of marriage and cohabitation on licit and illicit drug use. Demography, 43, 4, pp. 691-710. doi:10.1353/dem.2006.0032.

Elwert, F. \& Winship, C. (2014). Endogenous selection bias: The problem of conditioning on a collider variable. Annual Review of Sociology, 40, pp. 31-53. doi:10.1146/annurev-soc-071913-043455.

Eng, P. M., Kawachi, I., Fitzmaurice, G., \& Rimm, E. B. (2005). Effects of marital transitions on changes in dietary and other health behaviours in US male health professionals. Journal of Epidemiology and Community Health, 59, 1, pp. 56-62. doi:10.1136/jech.2004.020073.

Fallon, A. E. \& Rozin, P. (1985). Sex differences in perceptions of desirable body shape. Journal of Abnormal Psychology, 94, 1, pp. 102-105. http://psycnet.apa.org/buy/1985-14553-001.

Frisco, M. L., Weden, M. M., Lippert, A. M., \& Burnett, K. D. (2012). The multidimensional relationship between early adult body weight and women's childbearing experiences. Social Science \& Medicine, 74, 11, pp. 1703-1711. doi:10.1016/j.socscimed.2011.08.018. 
Garfield, C. F., Duncan, G., Gutina, A., et al. (2015). Longitudinal study of body mass index in young males and the transition to fatherhood. American Journal of Men's Health, pp. NP158-NP167. doi:10.1177/1557988315596224.

Goldstein, J., Kreyenfeld, M., Huinink, J. et al. (2010). Familie und Partnerschaft in Ost- und Westdeutschland: Ergebnisse im Rahmen des Projektes „,Demographic Differences in Life Course Dynamics in Eastern and Western Germany". Rostock: Max-Planck-Institut für demografische Forschung. https://www.demogr. mpg.de/files/press/1832_familie_und_partnerschaft_ost_west.pdf.

Gorber, S. C., Tremblay, M., Moher, D., \& Gorber, B. (2007). A comparison of direct vs. Self-report measures for assessing height, weight and body mass index: A systematic review. Obesity Reviews, 8, 4, pp. 307-326. doi:10.1111/j.1467-789X.2007.00347.x.

Harris, K. M., Lee, H., \& DeLeone, F. Y. (2010). Marriage and health in the transition to adulthood: Evidence for African Americans in the Add Health Study. Journal of Family Issues, 31,8, pp. 11061143. doi:10.1177/0192513X10365823.

Herman, C. P., Roth, D. A., \& Polivy, J. (2003). Effects of the presence of others on food intake: A normative interpretation. Psychological Bulletin, 129, 6, pp. 873-886. doi:10.1037/0033-2909.129.6.873.

Hetherington, M. M., Anderson, A. S., Norton, G. N. M., \& Newson, L. (2006). Situational effects on meal intake: A comparison of eating alone and eating with others. Physiology \& Behavior, 88, 4-5, pp. 498-505. doi:10.1016/j.physbeh.2006.04.025.

Heuveline, P. \& Timberlake, J. M. (2004). The role of cohabitation in family formation: The United States in comparative perspective. Journal of Marriage and Family, 66, 5, pp: 1214-1230. doi:10.1111/j.0022-2445.2004.00088.x.

Homish, G. G. \& Leonard, K. E. (2005). Spousal influence on smoking behaviors in a us community sample of newly married couples. Social Science \& Medicine, 61, 12, pp. 2557-2567. doi:10.1016/j.socscimed.2005.05.005.

Klein, T. (2011). „Durch dick und dünn.“ Zum Einfluss von Partnerschaft und Partnermarkt auf das Körpergewicht. KZfSS Kölner Zeitschrift für Soziologie und Sozialpsychologie, 63, 3, pp. 459-79. doi:10.1007/s11577-011-0143-4.

Klein, T., Rapp, I. \& Schneider, B. (2013). Der Einfluss der partnerschaftlichen Lebensform auf Rauchverhalten und Körpergewicht. Comparative Population Studies - Zeitschrift für Bevölkerungswissenschaft, 38, pp. 649-72. doi:10.4232/10.CPoS-2013-13de.

Kohn, J. L. \& Averett, S. L. (2014). The effect of relationship status on health with dynamic health and persistent relationships. Journal of Health Economics, 36, pp. 69-83. doi:10.1016/j.jhealeco.2014.03.010

Kopelman, P. G. (2000). Obesity as a medical problem. Nature, 404, 6778, pp. 635-643. doi: $10.1038 / 35007508$.

Lee, S., Cho, E., Grodstein, F., Kawachi, I., Hu, F. B., \& Colditz, G. A. (2005). Effects of marital transitions on changes in dietary and other health behaviours in US women. International Journal of Epidemiology, 34, 1, pp. 69-78. doi:10.1093/ije/dyh258.

Lundborg, P., Nystedt, P., \& Lindgren, B. (2007). Getting ready for the marriage market? The association between divorce risks and investments in attractive body mass among married europeans. Journal of Biosocial Science, 39, 4, pp. 531-544. doi:10.1017/S0021932006001611.

Marshall, D. W. \& Anderson, A. S. (2002). Proper meals in transition: Young married couples on the nature of eating together. Appetite, 39, 3, pp. 193-206. doi: 10.1006/appe.2002.0507.

Mata, J., Frank, R., \& Hertwig, R. (2015). Higher body mass index, less exercise, but healthier eating in married adults: Nine representative surveys across europe. Social Science \& Medicine, 138, pp. 119127. doi:10.1016/j.socscimed.2015.06.001.

McLaren, L. (2007). Socioeconomic status and obesity. Epidemiologic Reviews, 29, 1, pp. 29-48. doi:10.1093/epirev/mxm001.

Mensink, G. B. M., Schienkiewitz, A., Haftenberger, M., Lampert, T., Ziese, T., \& Scheidt-Nave, C. (2013). Übergewicht und Adipositas in Deutschland. Bundesgesundheitsblatt-Gesundheitsfor- 
schung-Gesundheitsschutz, 56, 5-6, pp. 786-794.

http://www.gbe-bund.de/pdf/DEGS1_Uebergewicht_Adipositas.pdf.

Mikkelsen, K. L., Heimann, B. L., Keiding, N., \& Sorensen, T. I. A. (1999). Independent effects of stable and changing body weight on total mortality. Epidemiology, 10, 6, pp. 671-78. http://www.jstor.org/stable/3703506.

Mukhopadhyay, S. (2008). Do women value marriage more? The effect of obesity on cohabitation and marriage in the USA. Review of Economics of the Household, 6, 2, pp. 111-126. doi:10.1007/s11150-007-9025-y.

Ng, S. P., Korda, R., Clements, M., et al. (2011). Validity of self-reported height and weight and derived body mass index in middle-aged and elderly individuals in Australia. Australian and New Zealand Journal of Public Health, 35, 6, pp. 557-563. doi:10.1111/j.1753-6405.2011.00742.x.

Nomaguchi, K. M. \& Bianchi, S. M. (2004). Exercise time: Gender differences in the effects of marriage, parenthood, and employment. Journal of Marriage and Family, 66, 2, pp. 413-430. doi:10.1111/j.1741-3737.2004.00029.x.

Ogden, C. L., Carroll, M. D., Curtin, L. R. et al. (2006). Prevalence of overweight and obesity in the United States, 1999-2004. JAMA, 295, 13, pp. 1549-55. doi:10.1001/jama.295.13.1549.

Oppenheimer, V. K. (1988). A theory of marriage timing. American Journal of Sociology, pp. 563-591. doi:10.1086/229030.

Perelli-Harris, B., Kreyenfeld, M., Sigle-Rushton, W.et al. (2012). Changes in union status during the transition to parenthood in eleven european countries, 1970s to early 2000s. Population Studies, 66, 2, pp. 167-182. doi:10.1080/00324728.2012.673004.

Puhl, R. \& Brownell, K. D. (2001). Bias, discrimination, and obesity. Obesity Research, 9, 12, pp. 788805. doi:10.1038/oby.2001.108.

Rapp, I. \& Schneider, B. (2013). The impacts of marriage, cohabitation and dating relationships on weekly self-reported physical activity in germany: A 19-year longitudinal study. Social Science \& Medicine, 98, pp. 197-203. doi:10.1016/j.socscimed.2013.09.024.

Rauschenbach, B., Sobal, J., \& Frongillo, E. A. (1995). The influence of change in marital status on weight change over one year. Obesity Research, 3, 4, pp. 319-27. doi:10.1002/j.1550-8528.1995.tb00157.x.

Schmeer, K. K. (2012). Union transitions and changes in BMI among adults in Mexico. Journal of Health and Social Behavior, 53, 2, pp. 263-275. doi:10.1177/0022146512445898.

Shafer, E. F. (2010). The effect of marriage on weight gain and propensity to become obese in the African American community. Journal of Family Issues, 31, 9, pp. 1166-1182. doi:10.1177/0192513X10366006.

Sobal, J., Rauschenbach, B., \& Frongillo, E. A. (2003). Marital status changes and body weight changes: A US longitudinal analysis. Social Science \& Medicine, 56, 7, pp. 1543-1555. doi:10.1016/S0277-9536(02)00155-7.

Tarlaci, S. (2012). The brain in love: Has neuroscience stolen the secret of love? NeuroQuantology, 10, 4, pp. 744-753. doi:10.14704/nq.2012.10.4.581.

Teachman, J. (2016). Body weight, marital status, and changes in marital status. Journal of Family Issues, 37, 1, pp. 74-96. doi:10.1177/0192513X13508404.

The, N. S. \& Gordon-Larsen, P. (2009). Entry into romantic partnership is associated with obesity. Obesity, 17, 7, pp. 1441-1447. doi:10.1038/oby.2009.97.

Umberson, D. (1992). Gender, marital status and the social control of health behavior. Social Science \& Medicine, 34, 8, pp: 907-917. https://s3.amazonaws.com/academia.edu.documents/42053939/Umberson_1992_SSM.pdf? AWSAccessKeyId=AKIAIWOWYYGZ2Y53UL3A\&Expires $=1535557844 \&$ Signature $=u 5$ THeu57 GTE\%2BWmXHaEinXPcDHPQ\%3D\&response-content-disposition=inline \%3B\%20filename \% 3DGender_marital_status_and_the_social_con.pdf.

Umberson, D., Liu, H., \& Powers, D. (2009). Marital status, marital transitions, and body weight. Journal of Health and Social Behavior, 50, 3, pp. 327-343. doi:10.1177/002214650905000306. 
Umberson, D., Liu, H., Mirowsky, J., \& Reczek, C. (2011). Parenthood and trajectories of change in body weight over the life course. Social Science \& Medicine, 73, 9, pp. 1323-1331. doi:10.1016/j.socscimed.2011.08.014.

Wadsworth, T. \& Pendergast, P. M. (2014). Obesity (sometimes) matters: The importance of context in the relationship between obesity and life satisfaction. Journal of Health and Social Behavior, 55, 2, pp. 196-214. doi:10.1177/0022146514533347.

Wilson, C. M. \& Oswald, A. J. (2005). How does marriage affect physical and psychological health? A survey of the longitudinal evidence. IZA Discussion Paper No. 1619. https://papers.srn.com/sol3/papers.cfm?abstract_id=735205.

Wilson, S. E. (2012). Marriage, gender and obesity in later life. Economics \& Human Biology, 10, 4, pp. 431-453. doi:10.1016/j.ehb.2012.04.012.

Wu, Z. \& Hart, R. (2002). The effects of marital and nonmarital union transition on health. Journal of Marriage and Family, 64, 2, pp: 420-432. doi:10.1111/j.1741-3737.2002.00420.x.

Submitted on/Eingereicht am: 27.11.2017

Accepted on/Angenommen am: 03.07.2018

Anschrift der Autorin/Address of the author:

Bernadette Huyer-May, Diplom-Soziologin

Institut für Soziologie

Ludwig-Maximilians-Universität München

Konradstraße 6

80801 München

Germany/Deutschland

Email/E-Mail: Bernadette.Huyer-May@soziologie.uni-muenchen.de 


\section{Appendix}

\section{Figure A1: Study flow diagram}

\section{Data Preparation}

- $\quad 31,683$ observations from 12,402 persons from W1, W3, W5 and W7 data

- 6 cases with implausible values for body height and body weight were deleted

- 5,030 observations were excluded with only one valid BMI observation

$\rightarrow 26,098$ observations from 7,863 persons

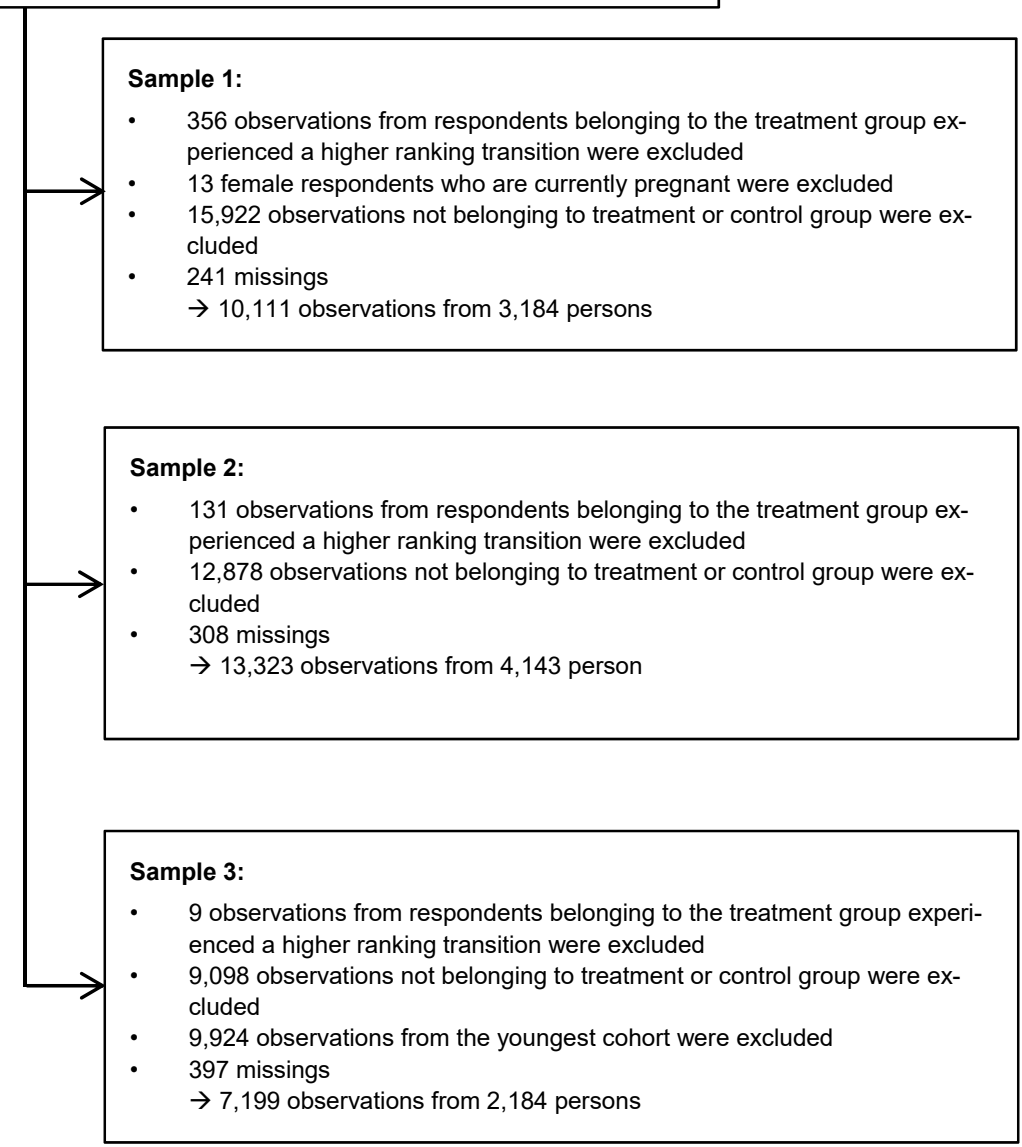

